ELECTRICAL PRINCIPLES III 
Macmillan Technician Series

P. Astley, Engineering Drawing and Design II

P. J. Avard and J. Cross, Workshop Processes and Materials I

G. D. Bishop, Electronics II

G. D. Bishop, Electronics III

John Elliott, Building Science and Materials

J. Ellis and N. Riches, Safety and Laboratory Practice

D. E. Hewítt, Engineering Science II

P. R. Lancaster and D. Mitchell, Mechanical Science III

R. Lewis, Physical Science I

Noel M. Morris, Electrical Principles II 


\title{
ELECTRICAL PRINCIPLES III
}

\author{
Noel M. Morris \\ Principal Lecturer, \\ North Staffordshire Polytechnic
}


All rights reserved. No part of this publication may be reproduced or transmitted, in any form or by any means, without permission.

First published 1978 by

THE MACMILLAN PRESS LTD

London and Basingstoke

Associated companies in Delhi Dublin

Hong Kong Johannesburg Lagos Melbourne

New York Singapore and Tokyo

Typeset in 10/12 Times

\section{British Library Cataloguing in Publication Data}

Morris, Noel Malcolm

Electrical principles III. - (Macmillan

technician series).

1. Electric engineering

I. Title

621.3

TK 145

ISBN 978-0-333-23103-6

DOI 10.1007/978-1-349-03550-2

This book is sold subject to the standard conditions of the Net Book Agreement.

The paperback edition of this book is sold subject to the condition that it shall not, by way of trade or otherwise, be lent, resold, hired out, or otherwise circulated without the publisher's prior consent in any form of binding or cover other than that in which it is published and without a similar condition including this condition being imposed on the subsequent purchaser. 


\section{Contents}

Preface

vii

\section{Circuit Theorems}

1.1 Maximum Power Transfer Theorem

1.2 Thévenin's Theorem

1.3 Norton's Theorem

1.4 The Relationship Between Thévenin's and Norton's Equivalent Circuits Problems

\section{Single-phase A.C. Circuits}

2.1 Series Circuit Containing Resistance and Inductance

2.2 Power, Volt-amperes, Reactive Volt-amperes and Power Factor

2.3 Series Circuit Containing Resistance and Capacitance

2.4 Series Circuit Containing Resistance, Inductance and Capacitance

2.5 Resonance in a Series Circuit

2.6 $Q$-factor of a Resonant Series Circuit

2.7 Parallel Circuit Containing $R$ and $L$

2.8 Parallel Circuit Containing $R$ and $C$

2.9 Parallel Circuit Containing $L$ and $C$

2.10 Parallel Circuit Containing $C$ in Parallel with $R L$

2.11 Parallel Resonance

$2.12 Q$-factor of a Parallel Resonant Circuit

2.13 Power Factor Correction Problems

\section{Three-phase Systems}

3.1 Generating Three-phase E.M.F.s.

3.2 Star Connection of Three-phase Windings
3.3 Three-phase, Four-wire, Star-connected Loads

3.4 Three-phase, Three-wire Balanced Star-connected Load

3.5 Delta (or Mesh) Connection

3.6 Power, VA and VAr Consumed by Balanced Three-phase Loads Problems

5. Principles of Rotating Electrical Machines

5.1 Types of Electrical Machine

5.2 Salient and Cylindrical Magnetic Systems

5.3 Basic E.M.F. Equation

5.4 Basic Torque Equation

5.5 Relationship Between the E.M.F. and Torque Equations

5.6 Types of Winding

5.7 Efficiency of Electrical Machines Problems

\section{D.C. Machines}

6.1 D.C. Machine Principles

6.2 Construction of D.C. Machines

6.3 E.M.F. Equation of the D.C. Machine

6.4 Torque Equation of the D.C. Machine

6.5 Armature Reaction

6.6 Commutation 
6.7 D.C. Machine Connections

6.8 Separately Excited Generator Characteristics

6.9 Shunt-wound Generator Characteristics

6.10 Series-wound Generator

6.11 Compound-wound Generator Characteristics

6.12 D.C. Motor Starters

6.13 Shunt Motor Characteristics

6.14 Series Motor Characteristics

6.15 Compound-wound Motor Characteristics

6.16 Speed Control of D.C. Motors

6.17 Efficiency of D.C. Machines

Problems

7. A.C. Motors

7.1 General Principles

7.2 Production of a Rotating Magnetic Field

7.3 Relationship Between Speed, Frequency and Number of Poles

7.4 Reversal of the Direction of the Rotating Field

7.5 Induction Motor Principle

7.6 Fractional Slip

7.7 The Cage Rotor Induction Motor

7.8 Synchronous Motors Problems

8. D.C. Transients

8.1 Response of a Resistive Circuit

8.2 Capacitor Charging Curves

8.3 Sketching Exponential Curves

8.4 Determination of the Transient Period or Settling Time

8.5 Capacitor Discharge Curves

8.6 Currents Associated with Charging and Discharging Capacitors

8.7 Effect of the Circuit Time Constant on a Square Wave

8.8 Growth of Current in an Inductive Circuit
8.9 Decay of Current in an Inductive Circuit

8.10 High Voltages Produced by Suddenly Open-circuiting an Inductive Circuit Problems

9. Measuring Instruments and Measurements

9.1 Measurement of Power in Single-phase Circuits

9.2 Measurement of Power in a Balanced Three-phase System

9.3 Measurement of Power in Three-phase, Three-wire Systems

9.4 The Decibel

9.5 dB Reference Levels

9.6 The Decibel as a Voltage or Current Ratio

9.7 Measurement of $Q$-factor

9.8 Electronic Analogue Measuring Instruments

9.9 Digital Voltmeters (D.V.M.s)

9.10 Measurement of Current and Resistance by Electronic Instruments

9.11 The Oscilloscope as a Measuring Instrument

9.12 Effect of Harmonics on Measurements

9.13 A.C. Bridge Circuits Problems

Solutions to Numerical Problems
70

70

72

73

74

76

76

78 


\section{Preface}

A sound knowledge of the principles of electricity is essential to technicians in all branches of the electrical and electronics industry; this book covers the requirements of Electrical Principles III and Electrical and Electronic Principles III of the Technician Education Council courses.

The nine chapters of the book provide coverage of the principal areas of work. The first chapter deals with important circuit theorems; there follows a chapter on a.c. circuits, including series circuits, parallel circuits and resonance. In chapter 3 the essentials of three-phase circuits are described. Chapter 4 is devoted to the principles of transformers, including not only the efficient use of power transformers but also the use of the transformer in the electronic field as an impedance matching device. Following this are three chapters on rotating machines; the first of these outlines the basic principles, while the second and third of these chapters deal with d.c. and a.c. machines respectively. Chapter 8 provides coverage of transients in d.c. circuits, and chapter 9 is devoted to measuring instruments and measurements including both the power and light-current fields.

I would like to thank the editorial and production staff of the Macmillan Press for their advice and help during the production of the book. It is also a pleasure to thank my wife for her excellent work during its preparation.

NOEL M. MORRIS

The cover photograph shows a Wayne Kerr Comparent Meter type B424, by courtesy of Wilmot Breeden Electronics Ltd. 